\title{
Study of Constitutional Court Decisions cancelling All Norms in the Law
}

\author{
Febriansyah Ramadhan $^{1 *}$, Ilham Dwi Rafiqi ${ }^{2}$
}

\footnotetext{
1,2 Faculty of Law, Universitas Brawijaya, Malang, East Java, 65145, Indonesia

*Corresponding author: mrfebri18@gmail.com
}

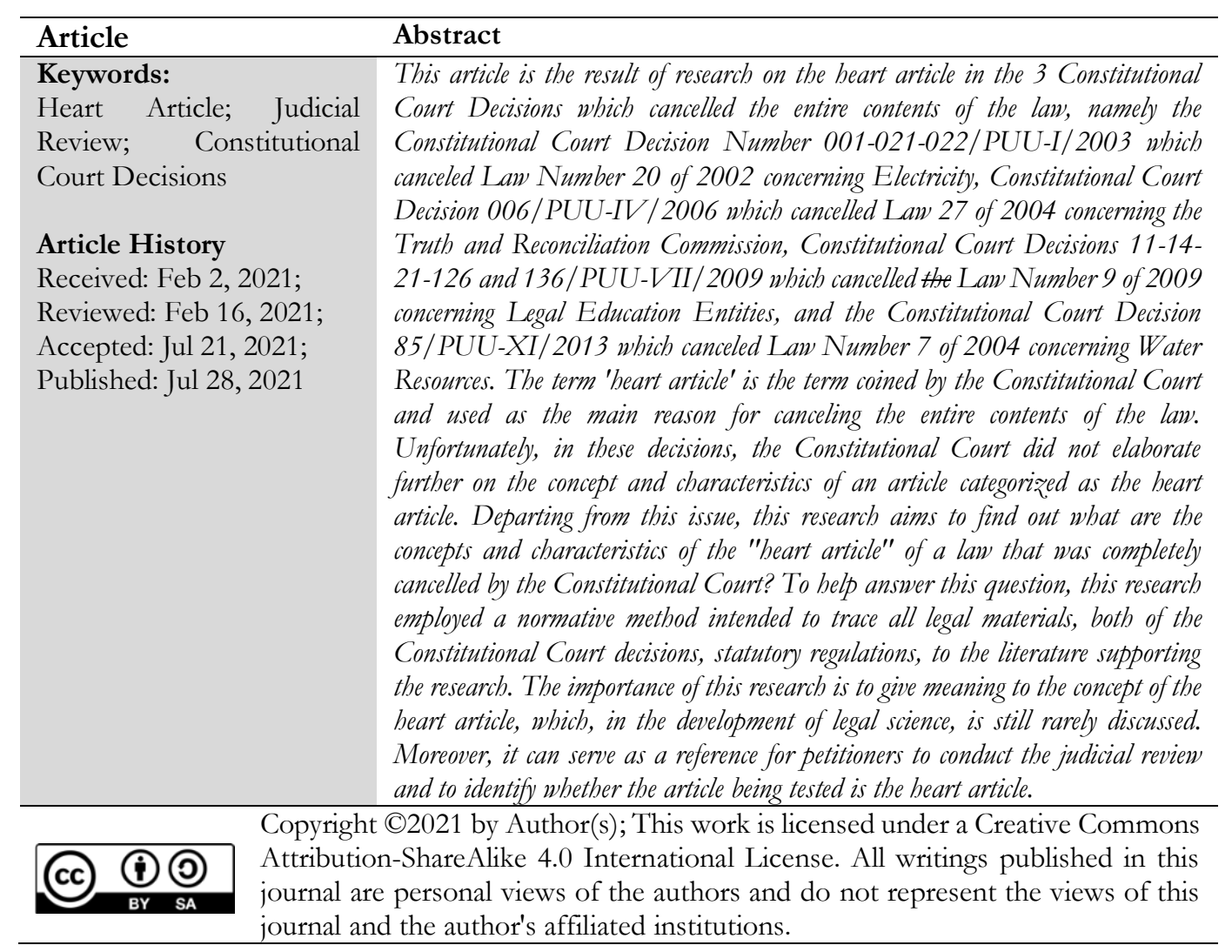

\section{INTRODUCTION}

This research focuses on the decision of the Constitutional Court (MK) which invalidates the entire contents of the law, especially those related to the "Heart article". The heart article is the term coined by the Constitutional Court in its Decisions which 
repeatedly invalidate the entire contents of the law. The Constitutional Court called the term "The heart article" in its consideration, and the article was unconstitutional so that all laws were canceled.

Like in medical science, the heart is a vital organ at the center of human life. If the heart is no longer beating/working, then of course people will lose their lives / die. This is the case with laws, when the heart Article of law is declared unconstitutional, the validity of all materials in the law no longer has legal/unconstitutional force. That was what was conveyed by the Constitutional Court. Unfortunately, up to 11 decisions that invalidated the entire contents of the law, the Constitutional Court gave a meaning to what the "heart article" is.

The annulment of the entire contents of the law is a form of judicial independence, because of the 11 Constitutional Court decisions that annulled the entire contents of the law, not all of them were requests of the petitioners, but some were initiated by the Constitutional Court. The Constitutional Court itself canceled the entire contents of the law without being requested by the petitioners. The basic this research is "every judge has the freedom to determine his opinion in every judicial review he handles" (Adonara, 2015).

Based on this thesis, there has been a wave of decisions that display various patterns and different interpretations of the touchstone of the Constitution. In a particular decision, the Constitutional Court possibly acts as judicial activism or clings to self-restraint. In practice, decisions with these patterns must be considered correct and implemented, but in the domain of law, especially in the development of science, they are not final.

In response to the decisions, validation, falsification, evaluation, and paradigmatic criticism must be carried out (Widarto, 2016). Moreover, currently, the court format, especially regarding court decisions, does not provide suggestions to test the consistency of the judges' personal views, opinions, or attitudes. As a result, as a theorist, it will be difficult to detect the judge's attitude and the consistency of his opinion personally.

The public is only presented with a decision with unanimous votes/considerations, the opinion of judge A/certain will only appear if he submits a dissenting opinion, if not - then the argument is unanimous. This study will conduct an examination of the article of the heart which is the creation of the Constitutional Court in the judicial review decision.

Judicial review is a mechanism carried out by the judicial power/MK to examine whether the contents and procedures of lawmaking are in accordance with the 1945 Indonesian Constitution. The authors consider Legislators/Presidents as 'hidden legislation'. The examination of laws comes with the hope that the laws formed are in line with the will of the 1945 Indonesian Constitution and do not have hidden purposes that have unilateral interests. Directly reviewed laws has provided control 
over the concrete activities carried out by the government because the government must do everything based on the law.

Judicial review also provides control over the implementation of a law. If the law carried out by the government is deemed to have impaired its constitutional rights, then the judicial review is present as a solution to the loss. In the notes of Walter F. Murphy explaining the role of judicial review: it may refer to review by judges of acts of government officials to determine whether the officers are acting under the authority of law exceeding powers granted by the statute (F. Murphy, et.al. 2005).

This description shows that the power between the legislators and the Constitutional Court indicates a very strong relationship in maintaining the principles of constitutionalism. In the United States, this power relation is symbolically represented in urban planning architecture in Washington DC - where The White House (executive power), the Capitol (legislative power), and the Supreme Court (judicial power) are adjacent. This symbol is considered to indicate that the three are pillars of the development of a democratic country. Even more extreme in the notes of Thomas J. Carrier in his work The White House, the Capitol, and the Supreme Court (DC), the three buildings have symbols. The distinctive structure do not have any other buildings, for sure (Thomas J. Carrier, 2000).

The Constitutional Court and legislators hold the same powers that articulate the meaning of the constitution into the text of a law; the interpretation made by the legislators aim to form a law, while the Constitutional Court's interpretation is intended to settle legal disputes. Each power has its own perspective in reading the constitutional text and tends to have its own truth. When legislators form legal products, they are not confronted with the needs/responses to the aspirations of the community, while the Constitutional Court gives a legal decision facing the petitioner's constitutional losses that do not appear immediately.

The activity of interpreting this constitution by the legislators and the Constitutional Court tends to lead to confrontation and has its own truth, but in the context of legal development, it is necessary to look at Waldron's opinion, which emphasizes to what extent the ability to identify errors in interpreting the constitution is avoided. More fully he says (H. Fallon, 2008):

Courts are no better than legislatures at defining rights correctly but maintain that the crucial question is not whether courts or legislatures are less likely to err, but which kinds of errors are most important to avoid - those that result in rights being overprotected or those that result in rights being infringed. Insofar as a judicial review can be designed to prevent errors in just one direction, involving failures to protect rights adequately, then judicial review may be supportable even if courts are no better than legislatures at identifying rights correctly.

The means of judicial review can actually be used as a stage for legislators to prove to the people their performance. If the law is canceled, of course, it will further add to the black record of the work of legislation. On the other hand, if it is rejected and the 
law is declared constitutional, then the legislators deserve to be proud while pointing out that they are on the right track, in which it strengthens their legitimacy. As Fallon puts it: judicial review can actually contribute to the political legitimacy of an otherwise democratic scheme of government when the demands of political legitimacy are understood correctly (H. Fallon, 2008).

Judicial review which invalidates the entire contents of the law certainly has special characteristics when compared to the other decisions. A law, which is the result of the performance of time-consuming and costly legislation and is then canceled, as a whole certainly presents a confrontational nuance between the judicial power and the legislators, especially when viewed from sentiment, the number of Constitutional Court judges with the number 9 can cancel what becomes the decision of hundreds of members of the DPR and the President who are the representatives of the people. This is where the supremacy of the constitution is tested. In the development in the last 17 years, there have been 11 Constitutional Court decisions that have canceled all contents of the law (Veri Junaidi, et, 2019):

1. Decision of the Constitutional Court Number 001-021-022/PUU-I/2003 concerning Judicial Review of Law Number 20 of 2002 concerning Electricity;

2. Decision of the Constitutional Court Number 013/PUU-I/2003 concerning Judicial Review of Law Number 16 of 2003 concerning Stipulation of Government Regulations in Lieu of Law Number 2 of 2002 concerning Enforcement of Government Regulations in Lieu of Law Number 1 of 2002 concerning the Eradication of Terrorism amended to the Bali Bombing Incidence on 12 October 2002

3. The Constitutional Court Decision Number 018/PUU-I/2003 concerning Judicial Review of Law Number 45 of 1999 concerning the Establishment of Irian Jaya Tengah Province, West Irian Jaya Province, Paniai Regency, Mimika Regency, Puncak Jaya Regency, and Sorong City, as amended by Law Number 5 the Year 2000;

4. The Constitutional Court Decision Number 006/PUU-IV/2006 concerning Judicial Review of Law Number 27 of 2004 concerning the Truth and Reconciliation Commission;

5. The Constitutional Court Decision Number 13/PUU-VI/2008 concerning Review of Law Number 16 the Year 2008 concerning Amendments to Law Number 45 the Year 2007 concerning the State Revenue and Expenditure Budget for the 2008 Fiscal Year;

6. The Constitutional Court Decision Number 11-14-21-126-136/PUU-VII/2009 concerning Judicial Review of Law Number 20 of 2003 concerning the National Education System and Law Number 9 of 2009 concerning Legal Education Entities, which invalidated the BHP Law; 
7. The Constitutional Court Decision Number 6-13-20/PUU-VIII/2010 concerning Judicial Review of Law Number 16 of 2004 concerning the Republic of Indonesia Public Prosecutor's Office and Law Number 4/PNPS/1963 concerning Safeguarding of Printed Goods that Disturb Public Order jo. Law Number 5 of 1969 concerning Statements of Various Presidential Decrees and Presidential Regulations as Laws, which canceled Law 4/PNPS/1963 jo. Law 5/1969;

8. Decision of the Constitutional Court Number 8/PUU-VIII/2010 concerning Judicial Review of Law Number 6 of 1954 concerning the Establishment of the Rights of DPR Inquiry;

9. The Constitutional Court Decision Number 28/PUU-XI/2013 concerning Judicial Review of Law Number 17 the Year 2012 concerning Cooperatives;

10. The Constitutional Court Decision Number 85/PUU-XI/2013 concerning Judicial Review of Law Number 7 of 2004 concerning Water Resources;

11. Decision of the Constitutional Court Number 1-2/PUU-XII/2014 concerning Review of Law Number 4 of 2014 concerning Stipulation of Government Regulations in Lieu of Law Number 1 of 20013 concerning the Second Amendment to Law Number 24 of 2003 concerning the Constitutional Court.

These decisions will be the focus of the discussion in this study. The fully cancelling Constitutional Court decision is a decision that is considered minimal when compared to the entire quantity of testing in the Constitutional Court. The discussion in the next section will discuss the explanation of these decisions. Explanations will be carried out to see that the initiative to submit a cancellation in its entirety actually comes from the petition of the petitioner or is a creation of the Constitutional Court.

In addition, it is necessary to carry out an analysis of the basis used by the Constitutional Court in making decisions. For example, in the Constitutional Court's decision on the Electricity Law, the Constitutional Court emphasized that the law was completely canceled because the "heart article" of the law was canceled ". So what is actually the heart Article?

In its decision, the Constitutional Court does not clearly explain what is the heart article, what are the characteristics/indicators? And is it true that in all the Constitutional Court decisions, the heart article is always used as the basis for canceling the entire contents of the law? This discussion will be discussed in the first discussion of this research. The Constitutional Court's decision canceling the contents of the law, of course, states that the entire contents of the law are constitutional. Needless to say, in law, it consists of various contents. However, the problem is that is it, apart from the heart article, an unconstitutional norm?

It is essential to discuss whether the legislators will only focus on reforming the heart article or they must change the entire content material. The focus in this research is to provide meaning or concept to the heart article. In some of the decisions above, 
one of the reasons for the Constitutional Court to cancel is because the heart articles in the law are unconstitutional, thus making all the material of the law ultimately constitutional. Then what is the true meaning of the heart Article, what is the concept behind it, what its characteristics are, and whether in all laws there is always a heart Article, and how to detect the heart Articles in every law?

Based on the above discussion, this research will discuss the concept and character of the heart articles existing in several decisions of the Constitutional Court. This research is also expected to help develop science, especially relating to court decisions, to serve as a means of information and knowledge on the Constitutional Court Decision which invalidates the entire contents of the Law, and to validate, falsify, and evaluate court decisions in order to provide critical discourse on law enforcement, especially in the Constitutional Court.

At a practical level, the urgency of this research is to provide information and knowledge to constitutional law practitioners in the Constitutional Court, to easily detect the various articles at the heart of each law, so that if indeed a problematic norm is the heart article, practitioners need not hesitate to call on the Constitutional Court to cancel the entire contents of the law as a form of evaluation of the performance of the legislation so far.

\section{METHOD}

This research employed a normative research method, which, according to Soerjono Soekanto, involves examining statutory regulations/positive law using library materials or mere secondary data" (Soekanto \& Mamudji, 1985). This can be seen in the main objects examined in this Decision, particularly the Decisions of the Constitutional Court which canceled the entire contents of laws.

Approaches used in this research constitute the statutory approach, philosophical approach historical approach, and conceptual approach. The main/primary legal materials used consisted of statutory regulations and the Constitutional Court Decisions which, in positive law, are at the same level as law. To assist research, secondary legal materials were also used consisting of literary sources such as books, research reports, journals, and the like which are supportive in nature (Marzuki, 2009).

In the framework of research effectiveness to interpret the heart Article of the Constitutional Court Decision which canceled all contents of the law, the research scope is restricted to no further than extracting the meaning of the heart Article from the five randomly selected decisions (random sampling):

1. The Constitutional Court Decision Number 001-021-022/PUU-I/2003 which invalidated Law Number 20 of 2002 concerning Electricity (Electricity Law) 
2. The Constitutional Court Decision Number 006/PUU-IV/2006 which canceled Law 27 of 2004 concerning the Truth and Reconciliation Commission (KKR Law)

3. The Constitutional Court Decisions Number 11-14-21-126 and 136/PUUVII/ 2009 which invalidated Law Number 9 of 2009 concerning Legal entities education

4. The Constitutional Court Decision Number 85/PUU-XI/2013 which canceled Law Number 7 of 2004 concerning Water Resources

\section{RESULTS AND DISCUSSION}

\section{Overview of the Decision of the Constitutional Court}

The development of knowledge, especially regarding the meaning/concept of the "heart article" is still relatively small, both in the science of legislation and in the procedural law of the Constitutional Court. The term heart article is another term from practice in the procedural law of the Constitutional Court, especially the decisions which are all norms in the law. The concept, character, and shape of the heart article itself have various patterns, which will be proven in the discussion in the last section. To date, the Constitutional Court has 11 decisions canceling the entire contents of the law, the reasons and considerations for annulment are very diverse, but almost the majority of these decisions emphasize that the heart article of the decision is unconstitutional. As a result, the entire norms in the law no longer have constitutional legitimacy, so that the Constitutional Court states that it has no binding legal force.

To give meaning to the heart article, this study uses 5 Constitutional Court decisions as a sample to be identified (see the following Table), so that we can get the whole picture of the meaning and essence of the heart article in judicial review.

Decisions canceling the entire contents of the law

\begin{tabular}{|c|c|c|c|c|c|}
\hline No & Decision & Petitioner & $\begin{array}{l}\text { Article being } \\
\text { Tested }\end{array}$ & Petitum & Information \\
\hline 1 & $\begin{array}{c}\text { 001-021- } \\
\text { 022/PUU- } \\
\text { I/2003 }\end{array}$ & $\begin{array}{l}\text { 1. APHI } \\
\text { (Association of } \\
\text { Indonesian } \\
\text { Legal and } \\
\text { Human Rights } \\
\text { Advisors) } \\
\text { 2. PBHI } \\
\text { (Indonesian } \\
\text { Legal Aid and } \\
\text { Human Rights } \\
\text { Association) } \\
\text { 3. Foundation } 324\end{array}$ & $\begin{array}{l}\text { Article } 20 \\
\text { paragraph (1), } 7, \\
8 \text { paragraph (2), } \\
\text { 16, } 17 \text { paragraph } \\
\text { (1) and (3), } 21 \text { (3), } \\
30 \text { paragraph (1), } \\
68 \text { Law Number } \\
20 \text { of } 2002 \\
\text { concerning } \\
\text { Electricity }\end{array}$ & $\begin{array}{l}\text { The } \\
\text { Petitioners } \\
\text { requested } \\
\text { entire } \\
\text { cancellation } \\
\text { of the } \\
\text { contents. }\end{array}$ & $\begin{array}{l}\text { In this } \\
\text { petition, the } \\
\text { petitioners } \\
\text { did not } \\
\text { request the } \\
\text { Constitutional } \\
\text { Court to } \\
\text { revive the } \\
\text { previous } \\
\text { Electricity } \\
\text { Law in } 1985 \text {. }\end{array}$ \\
\hline
\end{tabular}




\begin{tabular}{|c|c|c|c|c|c|}
\hline 2 & $\begin{array}{c}\text { 006/PUU- } \\
\mathrm{IV} / 2006\end{array}$ & $\begin{array}{l}\text { NGO: } \\
\text { Kontras, } \\
\text { Imparsial, } \\
\text { Citizen: } \\
\text { Waluya J, Tjasmarja } \\
\text { Setyo P. }\end{array}$ & $\begin{array}{l}\text { Articles } 1 \text { (9), } 27 \text {, } \\
\text { and } 44 \text { of Law } 27 \\
\text { of } 2004 \\
\text { concerning the } \\
\text { Truth and } \\
\text { Reconciliation } \\
\text { Commission }\end{array}$ & $\begin{array}{l}\text { Cancellation } \\
\text { of Article } \\
27 \text {, Article } \\
44 \text { and } \\
\text { Article } 1 \\
\text { Paragraph } \\
\text { (9) of the } \\
\text { KKR Law }\end{array}$ & $\begin{array}{l}\text { In this } \\
\text { petition, the } \\
\text { petitioners } \\
\text { did not } \\
\text { request the } \\
\text { cancellation } \\
\text { of the entire } \\
\text { contents of } \\
\text { the law. }\end{array}$ \\
\hline 3 & $\begin{array}{l}11-14-21- \\
126 \text { and } \\
136 / \text { PUU- } \\
\text { VII/2009 }\end{array}$ & $\begin{array}{l}\text { 1. Aep Saepudin. } \\
\text { 2. Kristiono Iman } \\
\text { Santoso }\end{array}$ & $\begin{array}{l}\text { Article } 6 \\
\text { paragraph (2), } \\
\text { Article } 9 \text { of Law } \\
\text { Number } 20 \text { of } \\
2003 \text { concerning } \\
\text { the National } \\
\text { Education System } \\
\text { and Article } 46 \text { of } \\
\text { Law Number } 9 \text { of } \\
2009 \text { concerning } \\
\text { Legal Education } \\
\text { Entities, and so } \\
\text { on. }\end{array}$ & $\begin{array}{l}\text { The } \\
\text { Petitioners } \\
\text { called for } \\
\text { only the } \\
\text { Articles to } \\
\text { be tested }\end{array}$ & $\begin{array}{l}\text { In this } \\
\text { petition, the } \\
\text { petitioners } \\
\text { did not } \\
\text { request the } \\
\text { cancellation } \\
\text { of the entire } \\
\text { contents of } \\
\text { the law. }\end{array}$ \\
\hline 4 & $\begin{array}{l}\text { 85/PUU- } \\
\text { XI/2013 }\end{array}$ & $\begin{array}{l}\text { 1. Pimpinan Pusat } \\
\text { Muhammadiyah } \\
\text { 2. Al Jami'yatul } \\
\text { Washliyah } \\
\text { 3. Solidaritas Juru } \\
\text { Parkir, } \\
\text { Pedagang Kaki } \\
\text { Lima, } \\
\text { Pengusha, dan } \\
\text { Karyawan } \\
\text { (SOJUPEK) } \\
\text { 4. Perkumpulan } \\
\text { Vanaprastha } \\
\text { 5. Citizen } \\
\text { (individual); } \\
\text { Drs. } \\
\text { Amidhan, } \\
\text { Marwan } \\
\text { Batubara, } \\
\text { Adhyaksa } \\
\text { Dault; Laode } \\
\text { Ida, M. Hatta }\end{array}$ & $\begin{array}{l}\text { Articles } 6-10, \\
26,29 \text { paragraph } \\
\text { (2) and paragraph } \\
\text { (5), } 45,46,48 \\
\text { paragraph (1), } 49 \\
\text { paragraph (1), 80, } \\
91,92 \text {, Law on } \\
\text { Water Resources }\end{array}$ & $\begin{array}{l}\text { The } \\
\text { Petitioners } \\
\text { requested } \\
\text { the a quo } \\
\text { law to be } \\
\text { canceled in } \\
\text { its entirety } \\
\text { and } \\
\text { requested } \\
\text { an } \\
\text { alternative } \\
\text { to the } \\
\text { cancellation } \\
\text { of several } \\
\text { articles as } \\
\text { proposed }\end{array}$ & $\begin{array}{l}\text { In this } \\
\text { petition, the } \\
\text { petitioners } \\
\text { did not call } \\
\text { on the } \\
\text { Constitutional } \\
\text { Court to re- } \\
\text { enforce Law } \\
\text { Number } 11 \\
\text { of } 1974 \\
\text { concerning } \\
\text { Irrigation }\end{array}$ \\
\hline
\end{tabular}




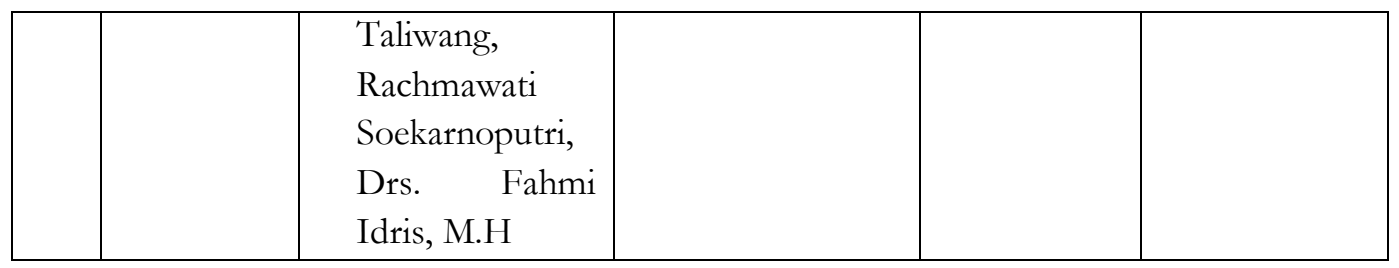

Table 1. A decision canceling the entire contents of the law (Junaidi, et, 2019)

To provide an overview of the five decisions, discussion clustering was carried out, namely regarding: 1 . The suitability between what the petitioners proposed and the Constitutional Court decided. 2. Implications of decisions on legal status in a certain legal spectrum.

First, in terms of the agreement between what the petitioners proposed and what was decided by the Constitutional Court, the Constitutional Court's decision to cancel the contents of the law came from the initiation of the petitioners and the Court. Regarding the review of the Electricity Law and the Water Resources Law, the petitioners in their petition have filed for cancellation of the entire contents of the law, and the Constitutional Court in its consideration granted what the petitioners submitted. Unlike the case with the KKR Law and the BPH Law, the petitioners may not have expected that the results obtained exceeded expectations because the petitioners did not specifically want to cancel all of them, but only related to certain articles. However, the initiative came from the Constitutional Court, which apparently states that the Articles being tested are the heart articles, which if canceled will have implications for the entire contents of the law.

At this stage, we find that the perspective for determining the heart Article has two patterns. The first pattern shows that the heart article came from the initiation of the petitioners which was later justified by the Constitutional Court in its decision. Meanwhile, the second pattern is that the petitioners 'allegedly' did not realize that the article they were testing was the heart article, so the point to determine that it was the heart article came from the Constitutional Court.

Second, in terms of the implications of these decisions, of the four decisions, the implications of these decisions also have various patterns. decisions are categorized into two major parts, namely decisions that revive the previous law, and decisions that do not get the follow-up. The first pattern is a decision that highlights the law, previously a decision on the trial of the Electricity Law.

In the petition of the two examiners, the petitioners simply canceled the entire contents of the law, without calling for the previous law to be enacted. If the petitioners do not serve, then of course the initiative will come from the Constitutional Court to revive it. The creation of the judges in giving decisions beyond what was requested, in this case, is to revive a law that has been revoked. Is it called ultra petite which is a variable of judicial activism? 
It is necessary to understand beforehand that legislative power could revive the law, and the Constitutional Court as a judicial body is bare of power to revive it. It can be said that the Constitutional Court's decision which revived the law was a form of transfer of legislative work from the legislators to the Constitutional Court. Is this justified? In the author's opinion, within the limits of reasonable reasoning, it is legal and permissible. In retrospect, why did the Constitutional Court revive the old law. This is to avoid a legal vacuum/rechtsvacum, because the existing laws have been completely annulled.

Although the petitioner did not expect it, the MK initiative was categorized as court activism, or commonly known as judicial activism. When the petition is not submitted, then the Constitutional Court gives a decision other than what was submitted, then the indication that leads to ultra petita is inevitable. In the judicial discourse, ultra petita decisions are not requested by petitioners or exceed what the petitioners request (Atmadjaja, 2012).

Ultra petita can be said to be a form/variable of judicial activism, where judges use their independence to make breakthroughs and legal creativity which is are always opposed vis-à-vis self-restraint. Black law dictionary explains: A philosophy of judicial decision-making whereby judges allow their personal views about public policy, among other factors, to guide their decisions with the suggestion that adherents of this philosophy tend to find constitutional violations and are willing to ignore precedent (Faiz, 2016).

In order to take a deeper look at the Constitutional Court Decision which revived laws that had been revoked from the judicial activism approach, it is necessary to look at the dimensions of judicial activism expressed by Bradley C. Canon, cited by Pan Mohammad Faiz. He categorized six dimensions of judicial activism, namely (Canon, 1983):

1. Majoritarianism: This dimension looks at the extent to which policies that have been taken and adopted based on the democratic process are negated by the judicial process;

2. Interpretive Stability: This dimension considers the extent to which previous decisions, doctrines, and interpretations of a court are changed again;

3. Interpretive Fidelity: The third dimension describes the extent to which articles in the constitution are interpreted differently from what is clearly meant by the constitution maker or what is clearly legible from the language used;

4. Substance / Democratic Process Distinction: This dimension looks at the extent to which court decisions have made substantive policies compared to safeguarding the decided outcomes of democratic political processes;

5. Specificity of Policy: The fifth dimension analyzes the extent to which a court decision forms its own policy which contradicts the principle of discretion held by other institutions or individuals; 
6. Availability of an Alternate Policymaker: This last dimension considers the extent to which a court decision replaces important considerations made by other government agencies.

If categorized by Bradley's approach, the Constitutional Court Ruling that revives the old law is the Availability of Alternative Policy Makers. The Constitutional Court's decision which brought the old law to life was from the court which took the legislative role of the legislators, with very basic considerations, especially regarding the legal vacuum.

The Constitutional Court in this case takes the role of forming an alternative policy because if it is returned to the law, the formation will take a long time, which in turn will lead to a legal vacuum. Judging from the enforceability, the old law is of course for a period of time, until the legislators re-form the new law.

Apart from the old law which was revived by the Constitutional Court, there were several decisions that later did not receive any follow-up, such as the KKR Law and the BPH Law. The KKR Law which was formed in 2004, was canceled in 2006, and to this day there has been no follow-up. Of course, the Constitutional Court's steps in 2006 which canceled the contents of the TRC Law entirely also needed to be reconsidered. The message received from this decision was that not every Constitutional Court Decision that canceled the entire contents of the law had beneficial effects. In the Decision of the KKR Law, the Constitutional Court gave a constitutional mandate.

The constitutional mandate is given by the Constitutional Court as a judicial institution by giving orders/signs to legislators to evaluate certain legal products in the future. A constitutional mandate, referred to by Peter Paczolay as a mandamus, is to legislate (Suroso, 2018). Of the various decisions that exist, the constitutional mandate of the legislators can be seen as follows (Suroso, 2018):

The fact that the TRC Law does not have binding legal force as a whole does not mean that efforts to resolve gross human rights in the past are done through reconciliation. There are many ways that can be achieved, other than by realizing reconciliation in the form of legal policies (laws) which are in line with the 1945 Constitution and universally applicable human rights instruments, or by carrying out reconciliation through political policies in the context of rehabilitation and amnesty in general.

The constitutional mandate in this decision is to provide signs, that in the future settlement through reconciliation is permissible / not to question/prohibit whatever is allowed, as long as it is guided and in accordance with universal human rights principles and the 1945 Indonesian Constitution. Unlike the Electricity Law, The TRC Law is a new law, not a law resulting from amendments, so it is impossible for the Constitutional Court to take an Alternate Policymaker step like other decisions. Likewise, with the BPH Law, this law has not received any follow-up from the laws since it was canceled until 2020. 
The BPH Law is also a new law, which has no previous regulations, so it is impossible for the Constitutional Court to take steps. The heart Article has two patterns. The first pattern shows that the heart article came from the initiation of the petitioners which was later justified by the Constitutional Court in its decision.

Meanwhile, the second pattern, the petitioners "allegedly" did not realize that the article they were testing was the heart article, so the angle to determine that it was the heart article came from the Constitutional Court. So, in the second discussion, it is found that the annulment of the entire contents of the law is accompanied by the revival of the old law 'if' the law being tested is an amendment from the previous law. If it does not have a previous or new law, the MK stops at cancellation only. This is the overview of the Constitutional Court Decision which annuls the entire contents of the law.

\section{Finding the Heart Article}

\section{The Constitutional Court Decision 001-021-022/PUU-I/2003 concerning} the Testing of the Electricity Law

In this study, this decision was the main sample chosen, because this decision was the first decision by the Constitutional Court to cancel the entire contents of the Electricity Law. In its consideration, the Constitutional Court stated that the article declared unconstitutional was the heart article, so that the entire contents of the law were also declared contrary to the 1945 Indonesian Constitution:

\begin{tabular}{|c|l|}
\hline Number & \multicolumn{1}{|c|}{ Article } \\
\hline 16 & $\begin{array}{l}\text { The electricity supply business as referred to in Article 8 paragraph (2) shall be } \\
\text { conducted by a different Business Entity. }\end{array}$ \\
\hline $\begin{array}{c}17 \text { ayat } \\
(2)\end{array}$ & $\begin{array}{l}\text { Electricity supply business as referred to in Article 8 paragraph (2) letter a shall } \\
\text { be conducted based on competition. }\end{array}$ \\
\hline 68 & $\begin{array}{l}\text { At the time this Law comes into effect, the Holders of the Electricity Business } \\
\text { Authority (PKUK) as referred to in Law Number 15 of 1985 concerning } \\
\text { Electricity are deemed to have had a license that is vertically integrated which } \\
\text { includes the generation, transmission, distribution and sale of electricity on a } \\
\text { regular basis. Carry out the duties and obligations of supplying electricity for the } \\
\text { public interest up to the issuance of the Electricity Supply Business Permit } \\
\text { based on this Law. }\end{array}$ \\
\hline
\end{tabular}

Tabel 2. The article being tested in Testing 001-021-022/PUU-I/2003

According to the Constitutional Court, Article 16 and Article 17 were declared contradictory to Article 33 of the 1945 Constitution where the assembly considered that electrical power was currently an important production branch that controlled the lives of many people and had to be controlled by the state. Therefore, the elements of privatization contained in the Article must be declared contradictory. In another part, the panel considers that the management of the electricity business should only be left 
to BUMN, in this case, PLN. Meanwhile, other national private companies or foreign companies will only participate if they are invited to cooperate with BUMN.

In this Decision, the heart articles are the core articles of the law where these norms did not exist in the previous law, namely concerning the involvement / private mechanism in the operation of electricity. That is, it can be said that the norm is a novelty of the previous law, which was then portrayed by the petitioners, and submitted to the Constitutional Court along with its constitutional impairment. A simple illustration is, if these norms are eliminated, then other norms will certainly not be implemented. That is why this chapter is called the heart chapter.

The main characteristic of this Article is the competition which is not allowed by the Constitution, in particular Article 33 of the Constitution regarding the management of natural resources. The Constitutional Court provides a standard controlled by the state, then based on these standards, the existence of this Article is tested, and the result is unconstitutional. This means that the heart Article in this examination is an Article that is contrary to the authentic meaning (original intent of the Constitution), and the Article is an Article that regulates the mechanism/procurement/involvement of the private sector in a law.

\section{The Constitutional Court Decision Number 006/PUU-IV/2006 concerning} the Judicial Review of the Truth and Reconciliation Commission Law

The idea for the formation of the KKR Law began with the desire to reveal the history of the truth of past interpretations that had never been exposed as an initial answer to provide a sense of justice for victims. It is important that the facts of the past are never forgotten, as learning material for the next generation so as not to repeat past mistakes.

So, what is expected in the real reconciliation process is an acknowledgment of the past history that allows victims (or their families) to open the door to forgiveness for perpetrators of gross human rights violations (Perdana Wiratrama, 2017). When viewed from the foundation of the formation of this law, orientation towards victims is the main focus for recovery, considering that disclosing past gross human rights violations is not easy, but justice for victims in any form must be fulfilled immediately and not drag on.

In 2006, a group of people submitted a review of the TRC Law to the Constitutional Court. There are two major groups of petitioners, namely NGOs, which consist of Elsam, et al. and individual citizens, namely Raharja Waluya Jati and $\mathrm{H}$. Tjasman Setyo Prawiro. In their petition, petitioners submitted a review of the KKR Law. In its decision, the Constitutional Court explicitly stated that the TRC Law was canceled because the heart article of the law, Article 27 of the KKR Law, was unconstitutional.

Compensation and rehabilitation as referred to in Article 19 can be granted if the amnesty request is granted. According to the article, compensation and rehabilitation 
will only be given to victims if there is forgiveness from the President for the perpetrators of serious human rights violations. According to the Constitutional Court, this is legal uncertainty that greatly prolongs the process of restoring justice for victims.

The reason the Constitutional Court canceled was that the existence of this Article would not support the principles and objectives of the KKR Law as stated in Articles 2 and 3, so that they were only false goals. The Constitutional Court further stated that: Considering that all these facts and circumstances cause the absence of legal certainty, both in the formulation of norms and the possibility of implementing the norm in the field to achieve the expected goals of reconciliation. With regard to the considerations described above, the Court is of the opinion that the principles and objectives of the TRC, as stipulated in Article 2 and Article 3 of the quo law, cannot possibly be realized because there is no guarantee of legal certainty (rechtsonzekerheid). Therefore, the Court considers the quo law as a whole contradicts the 1945 Indonesian Constitution so that it must be declared as having no binding legal force.

The characteristic of the heart article of this Decision is that if a norm is considered as a norm that is incapable of supporting the achievement of the objectives of the law, it is called the heart article.

3. Constitutional Court Decisions Number 11-14-21-126 and 136/PUU-VII/ 2009

This verdict is unique. If we imagine how the judicial preview will be implemented in Indonesia, then this decision can be a prototype regarding the relationship between the Constitutional Court and legislators. The BPH Bill at that time shocked the public, and there was a rejection because it had the nuances of liberalizing the world of education, to the point that the BPH Bill had not been promulgated, it had been brought by the public to the Constitutional Court for examination.

As a result, through Decision 021/PUU-IV/2006, the Constitutional Court ruled 'Unacceptable' because what was being tested was not a law, but it was still a bill. In this decision, the Constitutional Court provided constitutional guidelines for legislators informing the BPH Law in ratio decidendi:

In order for the law regarding educational legal entities which is ordered by Article 53 paragraph (4) of the National Education System Law in accordance with the 1945 Constitution, it is necessary to pay attention to the following matters: 1. Aspects of state functions to educate the nation's life (Fourth Paragraph of the Preamble), state obligations, and the government in the education sector as stipulated in Article 31 paragraph (2), paragraph (3), paragraph (4), and paragraph (5), as well as the rights and obligations of citizens in the education sector as determined by Article 31 paragraph (1) and paragraph (2), Article 28C paragraph (1) and paragraph (2), and Article 28 paragraph (1) (sic.) Of the 1945 Constitution; 2. Philosophical aspects, namely regarding the ideals to build a quality and meaningful national education system for the life of the nation, sociological aspects, namely the reality of the existing education administration including those organized by various foundations, associations, 
and so on, as well as juridical aspects that do not cause conflict with other laws and regulations related to legal entities; 3. Regulatory aspects regarding educational legal entities in the aforementioned laws must be an implementation of state responsibility and are not intended to reduce or avoid the state's constitutional obligations in the field of education, so as not to burden the community and/or students; 4 . Aspects of public aspirations must receive attention in the formation of laws regarding legal education bodies, so as not to cause chaos and new problems in the world of education in Indonesia.

Unfortunately, the legislators did not pay any attention to the signs given by the Constitutional Court. Upon the promulgation, the BPH Law was immediately tested, and the Constitutional Court canceled the law in its entirety. The Constitutional Court considered that the BHP Law had transferred the duties and responsibilities of the Government in the education sector. "With the existence of the BHP Law, the formal education mission which is the task of the government in Indonesia will be carried out by the Government Education Legal Entity (BHPP) and the Regional Government Education Legal Body (BHPPD).

Whereas the 1945 Indonesian Constitution stipulates that the main responsibility for education lies with the state. In addition, the BHP Law makes BHPP and BHPPD a determinant of the success of education. In an excerpt of consideration, the Constitutional Court said that: the forms of BHPP and BHPPD regulated in the BHP Law did not guarantee the achievement of national education goals and created legal uncertainty, even though according to the 1945 Constitution the state had a major role and responsibility.

The decision is, the petitioners do not propose cancellation of the entire contents of the law but only to certain articles. The petitioners submitted Articles deemed to be the heart Article, namely Articles 37-59 of the BHP Law, where the Articles basically show the transfer of responsibility from the state to BHPPD and BHPP.

The articles were analyzed by the Constitutional Court in their consideration, and the existence of these articles were deemed to have violated the existence of the state as the person in charge of education. In an excerpt of his consideration, the Court was of the opinion: The forms of BHPP and BHPPD regulated in the BHP Law do not guarantee the achievement of the goals of national education and create legal uncertainty, even though according to the Constitution the state has the main roles and responsibilities.

The characteristics of the heart Article in this Decision are articles containing statutory norms that are contradictory to the obligations, authorities, and responsibilities stipulated by the Constitution. If the norms in a law contain material on obligations, authorities, duties, and responsibilities, and it is not like what is regulated by the Constitution, the norm can be said to be the heart article, which will cancel the entire contents of the law. 


\section{The Constitutional Court Decision Number 85/PUU-XI/2013 concerning the Testing of the Water Resources Law}

Understanding this decision, especially the structure of the Water Resources Law, certainly cannot be separated from the constitutional review of several other laws in the field of natural resources. The issue of privatization, commercialization, globalization vs. state sovereignty over natural resources is an inherent issue in every review of laws in the field of natural resources (Chandranegara, 2016). This Water Resources Law is considered to contain monopoly and commercialization by the private sector so that it does not accommodate the state's responsibility in the drinking water supply system in order to realize the principle of the greatest prosperity of the people (Puspitasari \& Nindyaningrum, 2015).

The constitutional review of the Natural Resources Law was not carried out only once in this decision. Previously, in 2005 there was also a constitutional review of the Natural Resources Law which resulted in the Constitutional Court Decision Number 008/PUU-III/2005, in which the Court in its decision did not cancel this Law but had a constitutional condition. It was only in this decision that the Court canceled the Water Resources Law, even overturned all norms in this law.

In this decision, the Constitutional Court clearly states that the right to control water is the "spirit or" heart "of the Water Resources Law as mandated by the 1945 Constitution of the Republic of Indonesia: (i) Control over water must not interfere with, override, let alone negate people's rights to water because the earth, water and natural resources contained therein must not only be controlled by the state, but also for the greatest benefit of the people ; (ii) The state is obliged to fulfill the people's right to water because access to water is a separate human right as referred to in Article 28I paragraph (4) of The 1945 Indonesian Constitution; (iii) environmental preservation, as in Article 28H paragraph (1) of The 1945 Indonesian Constitution; (iv) As a production sector which is important and controls the lives of the people, it must be controlled by the state and water according to Article 33 paragraph (3) of the 1945 Indonesian Constitution must be controlled by the state and used for the greatest prosperity of the people, so the state's supervision and control over water absolute; (v) As a continuation of the right to control by the state and because water is something which greatly affects the life of the entire people, the main priority given to control of water is the State-owned Enterprise or Regional-owned Enterprise; and (vi) If all of the aforementioned restrictions have been met and it turns out that there is still water availability, it is still possible for the government to grant permits to private businesses to carry out exploitation of water under certain and strict conditions (Constitutional Court Decision, Nomor 85/PUU-XI/2013, 2015, Paragraph [3.19]-[3.24]).

Considering that the articles put forward by the petitioners are also related to the practical aspects of the implementation of control and management of water resources in the field, the Court based on these principles will judge the implementing regulations 
as "norm delegation" of the law. After observing all implementing regulations, especially government regulations which consist of PP. 16 of 2005 concerning the Drinking Water Supply System, PP. 20 of 2006 concerning Irrigation, PP. 42 of 2008 concerning Water Resources Management, PP. 42 of 2008 concerning Groundwater, PP. 38 of 2011 concerning rivers, and PP. 73 of 2012 concerning Swamp, the Court concluded that 6 government regulations were deemed not fulfilling the principle of limiting and interpreting the control of rights to water.

In this decision, the Constitutional Court considers that the articles submitted by the petitioners are the heart of the Water Resources Law so that all norms in the law must be completely canceled. In addition to its important nature as the heart of articles, government regulations that are delegated from the proposed articles are also considered contrary to the principle of limiting and interpreting the control of the right to water so that it is appropriate to say that the Water Resources Law is unconstitutional, and it must be completely canceled. In addition to canceling the law, to avoid a legal vacuum, the Constitutional Court re-enacted Law Number 11 of 1974 concerning Irrigation.

\section{Interpreting the Heart Article}

The paradigm of the formulating and drafting the legislation is based on the imperative nature that maintains order and harmony from the highest norm hierarchy to its derivative norms. To keep the establishment to remain ideally, the existence of the Constitutional Court in addition to being the guardian of the constitution is also a guardian of the harmony of norms and their spirit from the highest hierarchy (UUD 1945) to the level of law. Allan R. Brewer-Carias in his article about Constitutional Court As Positive Legislators in Comparative, said that the existence of the contemporary Constitutional Court has a role as a supporting institution of legislators in carrying out the task of forming legislation, especially regarding maintaining the validity of norms in order to remain in the constitutional corridors whose positions are external (Brewer-Carías, 2010).

Related to the main focus of this article about the heart of article, the existence of the Constitutional Court is also intended to support the performance of legislators as stated by Allan R. Brewer-Carias. The duty of the Constitutional Court as a supporter is in a position that is quite extreme, in order that the court observantly reads every norm that is at the heart of a law, and when the norm is declared constitutionally invalid, it could immediately be cancelled in its entirety. The implications of the verdicts of the Court that canceled the norm entirely have 2 consequences: first, reenacting the previous regulations/laws. In this form of the award, if there is a preexisting law, such as Law concerning Electricity. Second, the court allowing for a lacuna in the law as in the case of KKR Law as the new law. 
The position of norms or articles in law is part/series of a single integrated system. As a system, the law requires synchronization, harmonization, and justification between one component and another. The system was built as a supporting instrument and as a means of achieving purposes / purposive behavior. The basis of system development is based on legal positivism thinking characterized by modern law and upholds legal order, order, and legal certainty.

In the perspective of the system, the laws formed by the authorities are arranged in an orderly manner and reject the 'random' character in the arrangement of norms. As a system, it will be composed of existing sub-systems and needs one another, as said by Elias M. Awad. The legal system that supports the achievement of goals can be seen as follows:

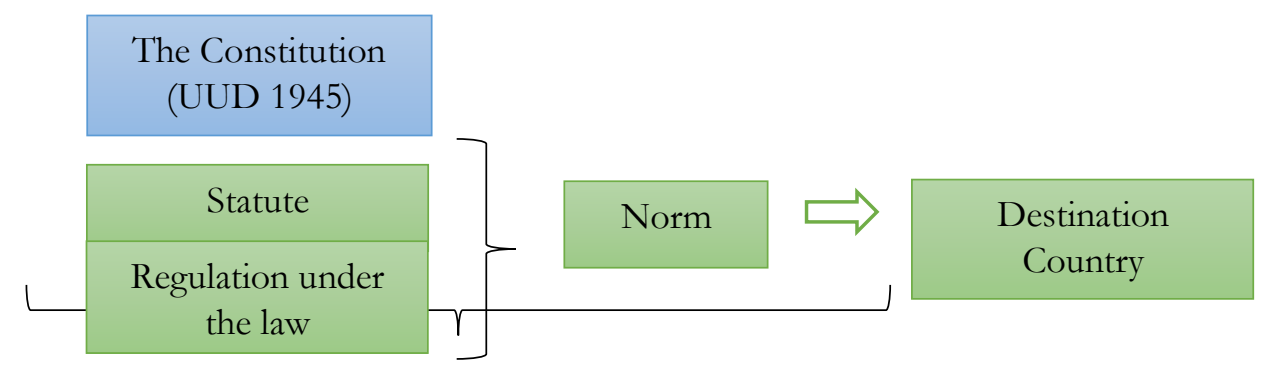

One unified system

Chart 1. Law as a Unified System to Achieve Goals (Salman \& Susanto, 2015)

The hierarchy of statutory regulations aims to determine the respective degrees in order to create a system of laws and regulations that are harmonious (there is harmony, suitability, harmony, balance), whereas disharmony is the existence of differences in boundaries, tension, and irregularities. In addition, the implication of hierarchy is the existence of legal norms in the same degree (in groups) so as not to contradict each other, for example, a group of norms in the form of laws also implies harmonious/appropriate norms and does not conflict with one law and another. The other invitation

Likewise, between articles or paragraphs from one another in law must also be harmonious. If it is contradictory, it actually causes the legal hierarchy/pyramid building to become porous and even damaged, it will further contradict the basic values contained in the Pancasila and the 1945 Indonesian Constitution and cause the legal state of Indonesia to not run in achieving its goals (Lailam, 2018).

A law consists of several parts. In general, a law is formed because there is a social need, or it is formed under order of the 1945 Indonesian Constitution. This is stated in the sociological and philosophical foundations contained in the considering part of 
the Preamble in the law. The underlying matter that will of course be discussed in the law is the purpose of the law being formed. In general, the purpose of formulating regulations is always discussed and studied in academic drafts, after which it is stated in the form of norms in law, therefore, usually the purpose of forming a law is always placed at the beginning of the law.

After knowing the goals to be achieved, then a system component is built to achieve these goals, starting from formulating principles as abstract guidelines in determining norms, determining related institutions, along with their authorities in carrying out rules, conditions, formulating prohibitions, to establishing sanctions imposed on any violations of prohibitions. The whole is a unified system that cannot be separated.

In the context of regulations as a system, of course, there are components that are the center, or core of a regulation, which, if these components do not work properly, or the components do not have harmonization with other regulations such as the 1945 Constitution, these components will certainly spoil the other order because it is the main component on which it is based. This component, in the development of law, is known as the heart article.

The cancellation of the heart article will spoil the entire system structure that exists in law. In the development of constitutional law, as well as in the science of legislation, discussion of the concept of the Heart Article is still theoretically rare. It could be that legislators do not know where in fact the articles at the heart of a law they make. The heart article can be found only in the Constitutional Court Decisions which cancel the entire contents of the law. But unfortunately, in these decisions, the Constitutional Court did not provide any further meaning, regarding the concept and characteristics of the heart article.

Based on research on the 3 decisions previously described, the concepts and characteristics of the article of the heart are understood. Of course, the authors must realize that the concepts and characteristics are based on the 3 Constitutional Court Decisions, so that to find the integrity and true truth, further research is needed on the other 8 decisions to find patterns from the heart article from the perspective of the Constitutional Court.

Conceptually, the article of the heart is a norm which is the core of the law, which, if the norm is damaged, or is declared as a norm that is contrary to other regulations, the law will lose its function, or in the sense that it will become null and void. It has binding legal force. To state an article is an article of the heart, in practice, it is always done through judicial review in the judiciary (Constitutional Court) with the Constitutional Court Decision as the output. To identify/find the heart article in law, the main testing instrument is the constitutional approach / UUD 1945. This is inseparable because the law is a supporting component of the 1945 Indonesian Constitution which was formed to achieve the goals of the state written in the 
constitution. If the existence of supporting components fails to realize its duties, the Constitution, through the Constitutional Court as its interpreter, will eliminate/delete the heart article.

Furthermore, what are the characteristics of determining a chapter as the heart chapter? To answer this question, the writer conducted a search of 3 Constitutional Court decisions and found 3 main characters, namely: First, one way to find out whether an article is a heart article is to test it with the purpose of the law. An article is said to be the heart article if the article becomes the most significant article to hinder the achievement of the objectives of the law. In general, the objectives of the law are always closely correlated with the objectives/guarantees of the constitutional rights of citizens which are stated in the constitution. If there is an article, which regulates the mechanism, or how to achieve the goal, but that method/mechanism is increasingly distracting, complicating, even negating the goal, then the article can be categorized as the article of the heart. Referring to constitutional approach and elaborating on existing practices are required to prove this.

Second, the next character of the heart chapter is contrary to the authentic meaning. The matter that the author limits, in this case, is about the authentic meaning / original intent of an organization including authority, duties, and responsibilities. When an article takes the meaning of authentic/original intent of the 1945 Constitution, it can be deemed to be the heart article. If the article is canceled, all operationalization along with its derivatives from the heart article will be invalidated.

Third, to radiate the spirit of liberalization / take a stance with a paradigm adopted in the Constitution. The 1945 Indonesian Constitution is a written legal document formed by the founders of the nation, which was later amended and is a representative of the history of the Indonesian nation's journey. As a historical document, the 1945 Constitution is the meeting point of the various ideologies/paradigms adopted before Indonesia's independence and agrees on Pancasila as the basis for an agreement extracted from the anthropological, sociological, and cultural conditions in Indonesia. Once said by Cheryl Saunders, a constitution is more than a social agreement. It is rather an expression of the general will of a nation. It is a reflection of its history, fears, concerns, aspirations, and indeed, the soul of the nation (Harjanti, 2015). As a historical document, of course, the 1945 Constitution is not limited to written texts which contain empty meanings, but rather contain principles, understandings, and paradigms in each of its article structures. To find the meanings of each of these articles, of course, what must be done is with a constitutional approach in the form of historical interpretation, philosophical interpretation, and several other interpretations to support the exploration of meaning.

An article in law is said to be the heart article if the article contains another paradigm as confirmed in the constitution. For example, according to the 1945 Constitution in terms of natural resource management, the effort that must be done is 
A, in a way that is A. The efforts and methods determined by the constitution are of course sourced from the paradigm/understanding of economic democracy, in which the state must create the maximum prosperity of the people. It turns out that in an article of the law it is stipulated differently, in the context of natural resource management, in which it is not based on A's efforts and A's methods, so that if the efforts and methods carried out are not based on the understanding adhered to by the 1945 Indonesian Constitution, it can be said that those efforts and methods are, not in line with the paradigm/understanding of economic democracy, and certainly not for the greatest prosperity of the people.

The meaning of the heart article, both in terms of concepts and characteristics, is carried out based on the approach of the 1945 Indonesian Constitution. With these concepts and characteristics, the stakeholders are expected to have a profound understanding of the formation of laws and judicial review, especially the practitioners of judicial review (petitioners/attorneys), so that in identifying the norms to be tested, they can understand the articles tested. If the article tested is a norm that belongs to the heart of the law, then based on past practice, it is possible to request a complete annulment, and this is part of a joint effort to fix the development of Indonesian law so that it remains based on constitutionalism and the 1945 Indonesian Constitution.

\section{CONCLUSION}

Indonesia's administrative journey shows that there were 11 laws that were completely canceled by the Constitutional Court. Regarding the decisions as the object of this research, it is found that there is no standard pattern in the examination. There are patterned decisions where the cancellation of all material laws is an initiative of the Constitutional Court without being submitted by petitioners. There is also another pattern, in which the heart article is submitted by a petitioner, and the Constitutional Court justifies it by granting and declaring all the material of the law tested is void.

Heart article is a norm that is the core of the law, in which if the norm is damaged, or is declared as a norm that is contrary to other regulations, the law will lose its function, or in the sense that it becomes null and has no binding legal force. To state an article is a heart article, in practice, it is always done through judicial review in the judiciary (Constitutional Court), with the Constitutional Court Decision as the output. The characteristics of the articles in the law can be referred to as the heart articles hindering the goal, contrary to the authentic meaning of the Constitution, especially regarding the authority, duties, and responsibilities of the organization, and radiating the spirit of liberalization / taking a stance with a paradigm adopted in the Constitution. 


\section{REFERENCES}

Adonara, F. F. (2015). Prinsip Kebebasan Hakim dalam Memutus Perkara Sebagai Amanat Konstitusi Principles of Fredom of Justice in Decidene The Case as a Constitutional Mandate. Jurnal Konstitusi, 12 (1), 1-20.

Atmadjaja, D. (2012). Putusan Ultra Petita Mabkamah Konstitusi. Jurnal Konstitusi, 115610.

Brewer-Carías, A. R. (2010). Constitutional Courts as "Positive Legislators" in the United States. American Journal of Comparative Law, 58(1), 479-504. https://doi.org/10.5131/ajcl.2009.0018

Canon, B. C. (1983)., Defining the Dimensions of Judicial Activism. Judicature, 66(6).

Chandranegara, I. S. (2016). Purifikasi Konstitusional Sumber Daya Air Indonesia (Constitutional Purification on Water Law). Jurnal Rechts Vinding Media Pembinaan Hukum Nasional, 5(3), 359-379. http://www.sinarharapan.co.id/berita/0310/27/ipt01.html.

Faiz, P. M. (2016). Dimensi Judicial Activism dalam Putusan Mabkamah Konstitusi. Jurnal Konstitusi, 13(2), 406. https://doi.org/10.31078/jk1328

Harjanti, B. M. \& S. D. (2015). Memahami Konstitusi: Makna dan Aktualisasi. Raja Grafindo Persada.

Lailam, T. (2018). Penataan Kelembagaan Pengujian Norma Hukum di Indonesia. Jurnal Konstitusi, 15(1), 206. https://doi.org/10.31078/jk15110

Mamudji, S. S. \& S. (1985). Penelitian Hukum Normatif. Rajawali Pers.

Marzuki, P. M. (2009). Penelitian Hukum (ke-5). Kencana Prenada Media Group.

Puspitasari, S., \& Nindyaningrum, U. (2015). Implikasi Putusan Makhamah Konstitusi Nomor 85/Puu-Xi/2013 Terhadap Sistem Penyediaan Air Minum. Jurnal Penelitian Hukum, 2(1), 48.

R. Herlambang Perdana Wiratraman, D. (2017). Laporan Penelitian: Dampak dan Implementasi Putusan Mabkamah Konstitusi yang memutuskan Pembatalan Undang-undang no. 27 tabun 2004 Tentang Komisi Kebenaran dan Rekonsiliasi Terhadap mekanisme bukum Dan Akses Keadilan Korban Bagi Penyelesaian Pelanggaran HAM

Richard H. Fallon, J. (2008). The Core Of An Uneasy Case For Judicial Review. Harvard Law Review, 121(7).

Suroso, F. L. (2018). Potret Relasi MK- Legislator, Konfrontatif atau Kooperatif? Genta Publishing.

Susanto, O. S. \& A. F. (2015). Teori Hukum, Mengingat, Mengumpulkan dan Membuka Kembali. Refika Aditama.

Thomas J. Carrier. (2000). The White House, the Capitol, and the Supreme Court: Historic SelfGuided Tours. Arcadia Publishing.

Veri Junaidi, et, al. (2019). Membaca 16 Tabun Mabkamah Konstitusi (MK): Data Uji Materi Undang-Undang terbadap UUD 1945 (2003-2019.

Walter F. Murphy, C. Herman Pritchett, J. K. (2005). Courts, Judges, and Politics: An 
Introduction to The Judicial procces. Mc Graw Hill.

Widarto, J. (2016). Penerapan Asas Putusan Hakim Harus Dianggap Benar (Studi Putusan Mabkamah Konstitusi Nomor 97/puu-xi/2013). Lex Jurnalica, 13(1). 